\title{
Belgeo
}

Revue belge de géographie

\section{Spatial planning as large-scale practical project: the problem of effective governance}

Ruimtelijke planning als grootschalig praktisch project: het probleem van

effectieve governance

\section{Pieter Saey}

\section{CpenEdition}

\section{Journals}

Electronic version

URL: http://journals.openedition.org/belgeo/15763

DOI: $10.4000 /$ belgeo.15763

ISSN: 2294-9135

\section{Publisher:}

National Committee of Geography of Belgium, Société Royale Belge de Géographie

\section{Printed version}

Date of publication: 30 September 2002

Number of pages: 295-310

ISSN: 1377-2368

\section{Electronic reference}

Pieter Saey, «Spatial planning as large-scale practical project: the problem of effective governance », Belgeo [Online], 3 | 2002, Online since 01 October 2002, connection on 19 April 2019. URL : http:// journals.openedition.org/belgeo/15763; DOI : 10.4000/belgeo.15763

This text was automatically generated on 19 April 2019

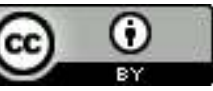

Belgeo est mis à disposition selon les termes de la licence Creative Commons Attribution 4.0 International. 


\title{
Spatial planning as large-scale practical project: the problem of effective governance
}

\author{
Ruimtelijke planning als grootschalig praktisch project: het probleem van \\ effectieve governance
}

Pieter Saey

(Spatial) planning is a form of methodical decision-making rather than the preparation of sound decisions, as was contended for a long time (Houthaeve, 1999, pp. 95-122). I take this to be a clear answer to the question asked by Kreukels back in 1980, whether steering of reality is a derivative of the stipulations of a plan, or, on the other hand, whether formation of plans is a derivative of the necessity of decision-making on the matters concerned (Kreukels, 1980, pp. 54-57). It is not only the answer implied in the decisioncentred view on planning, it is also the answer of planning theory after its communicative or linguistic turn. Healey says it plainly: planning in general is a kind of policy-driven style of governance (Healey, 1997, pp. 213-219). In this statement, governance refers to a general process, the management of collective affairs (ibid., p. 211). But governance has a more specific meaning as well: multi-scalar networked governance as opposed to hierarchical government. In this sense it applies to (spatial) planning. It captures the shift from planning as a purely rational enterprise to planning as a social practice, or, using the terms coined by Van der Valk (1989) and elucidated by Wallagh (1990), the shift from technocratic to sociocratic planning. This development has eventually led to Healey's collaborative planning, which presents itself as a kind of networked governance explicitly aimed at the promotion of democracy. Considered from this point of view, collaborative planning appears as the culmination of a certain line of development in planning theory and planning practice, characterized by the systematic enlargement of what Zonneveld (1991) has called the planning community. However, Houthaeve $(1999$, p. 161) notices a striking resemblance between Healey's ideas and the ideas of Saey (1995a, b), who, by an entirely different way, arrived at a similar plea to enlarge the planning community. Saey's plea is a consequence of his study of the 
theoretical foundations of town and country planning in Flanders before 1985 and the way in which this town and country planning was tied up with political decision-making (Saey, 1986-87). Saey identified town and country planning as a large-scale practical project in the sense of Ravetz (1973). Such large-scale practical projects have the tendency to fail, and Saey argued that the obvious way to counter this tendency was to give priority to enhancing democracy (looking for the best way to make a decision) over enhancing efficiency (looking for the best decision). This similarity between Healey's and Saey's ideas is at the heart of this article.

2 My purpose is to reflect on a meta-theoretical level upon the effectiveness of networked governance, of which collaborative spatial planning seems to be a textbook example, by linking the relevant ideas of Healey to the concept of a practical project as put forward by Saey. I want to answer the question of how effectiveness is guaranteed by strategic consensus-building and communicative rationality, the two cornerstones of collaborative planning in this respect. This will appear to be a question about the purpose or aspiration of collaborative planning, its theory of praxis, and the associated view of the societal field of action. The terms «purpose or aspiration», «theory of praxis», and «societal field of action» are explained in the first and the second sections (spatial planning as a practical project and the practicability of spatial planning), in which the view of Saey on spatial planning is summarized. The terms «strategic consensus-building» and «communicative rationality» are explained in the third section (the problem of effective governance), in which Healey's and Saey's ideas are compared.

\section{Spatial planning as a practical project: the example of Flemish town and country planning before 1985}

3 According to Saey $(1986-87,1988 b)$ it is no surprise that Flemish town and country planning has not been a success. Town and country planning is a large-scale practical project and these projects seldom meet the expectations. In contrast with technical projects, e.g., sending a man to the moon, practical projects are set up to improve a certain aspect of human welfare, in other words to solve a social or psychological problem. In the case of spatial planning, the social problem is improper use of space. In both types of projects, a distinction can be made between a task, a function, and a purpose or aspiration. The task consists of what has to be done: making rockets and lunar modules, making plans and regulations. The function relates to what use the task will be: to put a man on the moon, the role that plans and regulations play in decision-making. The purpose or aspiration consists of the reason why the technical or social problems have to be solved: to boost the national prestige, to guarantee sustainable spatial development ${ }^{1}$. A crucial distinction between a technical and a practical project is that, in the former, the goal of the task is performing a function, i.e., the task is determined by the function and not by the aspiration, whereas in the latter, the goal of the task is achieving a purpose, i.e., the aspiration is decisive in defining the task. The purpose of boosting the national prestige gives no clues to the technical requirements a lunar module should fulfil. These requirements are derived from the function (putting a man on the moon). On the other hand, the purpose of sustainable spatial development conditions the nature and content of plans and regulations. Plans and regulations will, or should, be different depending on whether the aspiration is sustainable development, strengthening of economic competitiveness, or a combination of both. In practical 
projects, it is quite possible that the task performs the function without achieving the purpose.

The concept of a practical project and the thesis that practical projects have the tendency to fail are taken from Ravetz (1973). Task, function, and purpose constitute the assignment of the project ${ }^{2}$. Saey (1988a, pp. 9-12; 1988b, pp. 55-56) identified two other components of a practical project: underlying views and design (see Table 1$)^{3}$. The underlying views are a view of society, a view of governance, and ends. The view of society relates to the developments in society that led to the social problem to be solved. It gives content and substance to the purpose. The view of governance makes the function meaningful. The ends relate, in the case of spatial planning, to the spatial organization aimed at, i.e., the organization of urbanization, spatial relationships, spatial differentiation, spatial hierarchy, and spatial justice ${ }^{4}$. The design should guarantee the feasibility of the project. Feasibility includes political and social attainability (the legitimization of the project), practicability (the problem of effectiveness), and workability (the bureaucratic organization and the type of planning and planning techniques to be applied).

Table 1. The components of a large-scale practical project.

\begin{tabular}{|c|c|c|}
\hline ASSIGNMENT & VIEWS & DESIGN \\
\hline purpose or aspiration & view of society & $\begin{array}{l}\text { effectiveness } \\
\text { (practicability) }\end{array}$ \\
\hline \multicolumn{2}{|c|}{ 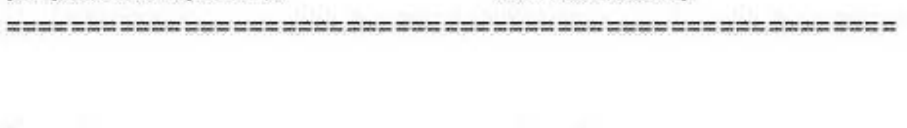 } & $\begin{array}{l}\text { legitimation } \\
\text { (attainability) } \\
===========\end{array}$ \\
\hline function & view of governance & $\begin{array}{l}\text { bureaucratic } \\
\text { organization and }\end{array}$ \\
\hline \multicolumn{2}{|c|}{ 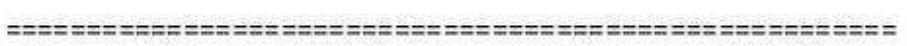 } & type of planning \\
\hline task & ends & $\begin{array}{l}\text { and techniques } \\
\text { (workability) }\end{array}$ \\
\hline
\end{tabular}

Bold: FOCUS OF THE ARTICLE

SOURCE: SAEY 1988A (MODIfIED)

6 Two features combine to produce a strong tendency to rigidity in large-scale practical projects, so that deterioration is nearly unavoidable: the initial ideological conception and the bureaucratic execution. The ideological conception determines from the outset the way in which the social problem will be specified, and within which limits solutions will be searched for. Once a social problem is formulated in a well-defined way, also the method of solution threatens to be fixed. Bureaucratic execution gives ample scope for goal displacements. Firstly, those involved in the execution have their own individual motives and purposes. It is not certain that these motives and purposes will harmonize with the assignment of the project. The challenging technical problems, which will appear especially in the early stages of the bureaucratic execution, are the second source of goal displacements. Functions are easier to specify than social aspirations and their fulfilment can more easily be established than the achievement of purposes. Finally, goal displacements occur when the bureaucracy starts to fall back on routine and turns into a bureaucracy in the pejorative sense. Any rigidity in the approach to a practical problem means there is minimal feedback or recycling. Mismanagement will be underestimated by 
the restricted awareness, caused by the initial ideological conception, of what is going on in reality. As a rule, the problem is so comprehensive that the proposed solutions are executed only when the problem has already changed shape. Also, the ideological conception and bureaucratic inertia make it difficult to learn from mistakes (Ravetz 1973, pp. 339-344).

Saey (1986-87, pp. 280-286; 1988b) has shown how town and country planning in Flanders exhibited many of the characteristics of the common cycle of a new practical project - «to proceed from a grand ideal conception, into a morass of difficulties of execution and then either lurch forwards into a final collapse or to survive, in a battered state, accomplishing tasks which have little relevance to the original purpose, or perhaps to any at all» (Ravetz, 1973, p. 344). The original aspiration, a rational and harmonious use of space for the benefit of the economy, housing, the beauty of the landscape, and welfare in general a grand conception indeed - was reduced to a purely pragmatic purpose, the reconciliation of all opposite interests by guaranteeing enough pieces of land for the bearers of these interests. This striking goal displacement was linked to a reduction of the function. The original function was the co-ordination of public policy and private initiatives regarding land use. This function was narrowed down to exclude administrative arbitrariness in deciding on allotment and building licences (Saey 1988a, p. 136, 141; 1988b, pp. 57-60). At an early stage, legal security was given priority, and the reduced function started to dominate. Regional plans, provided for by the Town and Country Planning Act of 1962 and originally considered to be the cornerstone of the planning system, were never drawn up. District plans, originally conceived as structure plans, became land use plans of cadastral precision. They started to serve as general municipality plans, being at the same time the plans of the highest level of bureaucracy (they were drawn up by the national administration). The preliminary plans bore the stamp of an economistic view of spatial organization, and when, in the early seventies, the ecological movement was in the ascendant and its ideals gained moderate approval with the authorities, it appeared very difficult to change the land use delineated in the draft plans. Only marginal modifications were made. Although the district plans performed their function (exclusion of administrative arbitrariness) reasonably well, eventually they appeared to fulfil not even their own ends, of gaining control of suburbanization. They have become part of the problem of improper use of space.

8 Saey $(1986-87$, pp. $280-286 ; 1988 b)$ tries to explain the fact that Flemish town and country planning has followed this common cycle of a new practical project by bringing political decision-making into the analysis. He contends that town and country planning was not an item of high priority on the political agenda because it cut right through the divisions between the political families. With Huyse $(1981,1983)$ he holds the view that only those problems that admitted of a standardized solution took priority, i.e., they could be transformed into a problem about which the political families (socialists, liberals and Christian Democrats) could reach an agreement via the standard channels of neocorporatist consultation and of pacification (concluding a pact on cultural, educational, and community matters by leading figures of the so-called pillars ${ }^{5}$ or political parties, which is afterwards approved by Parliament, which thereupon allocates the money to execute the agreement). According to Saey (ibid.), town and country planning did not get the opportunity to develop as an autonomous domain of policy. This was prevented by the influence of the executive (the government, and the competent minister and his 
extended secretariat, which acts as a personal advisory body) and by clientelism on all administrative levels.

9 Saey reached the conclusion that, in order to be able to counter the tendency towards deterioration, the first thing to do was to politicize town and country planning. He suggested doing more justice to the societal role of town and country planning, which, in his opinion, consists of the regulation of a social struggle for collective interests. This suggestion was based on the rejection of the conceptions of practicability that characterized the design of Flemish town and country planning and of a number of proposals to improve that planning. These conceptions include a theory of praxis (how to intervene in social reality) and an image of the societal field of action.

\section{The practicability of spatial planning}

\section{Theories of praxis and societal field of action} to investigate the historical economic development, from which these classes [bourgeoisie and proletariat] necessarily have arisen, and to discover the means to solve the conflict in the thus created economic situation... Former socialism criticized the existing capitalist mode of production and its results, but was not able to explain and surmount them; it only could reject them as evil ... [T] he means to remove the revealed abuses must be present - in a more or less developed stage - in the changing relations of production. These means should not be invented by reason just like that, but reason should lay them bare in the existing material facts» (Engels, 1971, p. 54, 56; own translation). argues that the same difference can be found in the discourses by which town and country planning were justified, but, as things are more complicated than Engels suggested, he prefers to speak of means-end and structural theories rather than of Utopian and scientific theories. In a means-end theory of praxis, it is thought that social problems can be solved by striving for an ideal situation that is defined on purely normative grounds and not related to the causes of the social problems. The advocated public policy is conceived as being the means to obtain the ideal situation. According to Saey (1988a, pp. 36-39; 1988c, pp. 181-182), this pattern of thought was followed, for example, in the parliamentary discussion of the Town and Country Planning Bill of 1961/62. In a structural theory of praxis, the justification for a particular policy is related to a theory of society that identifies the causes of the social problems to be solved by that policy, and determines the degree to which social structures and power relations impose limits on government intervention. This kind of theory of praxis is, in Saey's opinion, implied in the discourse of the planners who drew up the preliminary district plans and the early master plans that were intended as forerunners of the regional plans (which were never made). He identified the theory of society involved as social/human ecology (Saey, 1988a, pp. 57-61; 1988c, pp. 183; 1989, pp. 22-23). However, Saey found two further features about theories of praxis: there exists a third category besides means-end and structural theories, and different (categories of) theories can have the same view on the societal field of action. 

continued existence of social problems is attributed to the shortcomings of the present public policy, and as a consequence, the solution is sought in a new policy that is derived from a theory of decision-making and policy implementation. A formal theory of praxis takes it for granted that society is made up in such a way that it will yield to the kind of decision-making and policy implementation that the theory at hand requires. Discourses that exhibited the characteristics of such a formal theory were found in some reports of research centres that were asked by the then National Town and Country Planning Commission to propose an alternative to the physical planning applied in the district plans. One of the centres proposed, for example, a voluntary structure planning. This alternative operated on the basis of consensus building and took it for granted that, even though opposite views are present in society, a consensus on the view of society that underlies the assignment of the practical project of spatial planning, is possible. In this way, theory of society has been replaced by planning theory (Saey, 1988a, pp. 89-92, 146-149, 152; 1988c, pp. 185-186).

Whether or not a theory of praxis is tied up with a theory of society, it always implies a certain conception of what may be called the societal space of action. This space of action is characterized by a distribution of social relations and power relations, within which human beings occupy positions that make them participate in social practices in a differential way. A Marxist will conceive this space as a field of action of social classes. A nationalist will see a field of action of peoples or nations. A certain research tradition in economics will see a game theoretic field of action of individual and collective actors. In a similar way, the discourses analysed by Saey were implicitly or explicitly linked to a specific conception of the action space. This conception, as described by Saey (1989, pp. 20-24) ${ }^{6}$ envisages a field of action divided into two spheres, the sphere of social development and the sphere of politics. The sphere of social development includes the processes of modernization, which manifest themselves in the behaviour of groups of actors, who are recognized by the specific way in which they make use of geographical space. The sphere of politics includes those who participate in the regulation of social development: the politicians and bureaucrats who staff the apparatus of government, and the interest groups and experts who (try to) influence public policy. The possibilities of social action consist of the policy-driven intervention of the authorities in the components of the sphere of social development. However, the processes of modernization are hardly susceptible to political steering. Therefore, possibilities of intervention are sought in the regulation of the claims of existential functions (living, working, recreation, etc.) on geographical space.

\section{Social struggle for collective interests}

Saey was of the opinion that this view of the societal field of action has contributed to the rigidity and the ensuing failure of the practical project of Flemish town and country planning. His alternative was a structural theory of praxis with historical materialism as a theory of society (Saey, 1986-87, 1989) ${ }^{7}$. The basic idea was that:

«social struggle, waged by social movements, makes human beings conscious of the fact that desirable purposes, which till then did not even belong to the imagination, are brought within reach through the formation of new social relations. Desirable purposes refer to collective interests. Collective interests, like all sectional interests, originate in certain social positions and situations, but, in contrast with 
other sectional interests, they exert an attraction on other social groups. This attraction derives from the development of a comprehensive ideology. Its existence is proved through social struggle and reaches so far that members of nearly all social strata side with the movement» (Saey, 1989, p. 25).

The field of action associated with this theory of praxis is structured by class relations, civil society, and the (central, regional, and local) state. This structuring of the societal space of action is based on an identification of the relevant part of Cooke's conceptual framework for planning and spatial development (Cooke, 1983, pp. 264-271) with the concept of field of action. The countless issues or sources of action and mobilization belong to five spheres that are conceived as loci of social struggle: (i) the sphere of production or the area of encounter between labour and capital, fighting about issues such as productivity, discipline on the shop floor, and influence of the unions; (ii) the sphere of circulation or the locus of struggle over profits between fractions of capital, and over wages between labour and capital in the various branches and industries; (iii) the sphere of reproduction or the locus of largely class-based struggle over education, housing, health care, recreation, entry to the labour market, and the development and location of new branches of industry; (iv) the sphere of popular-democratic struggle over issues such as culture, gender, environment, religion, and language; (v) the sphere of politics and its channels of decision-making. Not only the spheres of circulation, reproduction, and popular-democratic struggle - which constitute the field of civil society - but all spheres interpenetrate. The degree of interpenetration itself is an important source of action and mobilization (Saey, 1986-87, pp. 294-297; 1989, pp. 25-27).

\section{The sphere of politics}

Pacification and neo-corporatist consultation are parallel channels of political decisionmaking in the sense that they substitute themselves for the parliamentary channel, in which the Parliament, as the bearer of the will of the nation, designated by the Constitution, charges the Government with orders via the formation of a political majority (Huyse, 1981). They are examples of the interpenetration of the spheres of circulation/reproduction/popular-democratic struggle and the sphere of politics. According to Saey (1986-87, p. 247; 1988b, pp. 63-64), the decision-making in town and country planning followed a kind of smothered parallel channel. He called it a parallel channel because town and country planning had become a matter on which Parliament had no longer any decision power, comparable to the matters that are subject to neocorporatist deals. Parliament could only criticize and applaud. However, it was not a fully-fledged channel of decision-making. The advisory and consultative bodies were disproportionately manned by representatives of the traditional interest groups. Moreover, neither these bodies nor the planners participated in the final decisions as, in the final stage, the secretariat of the competent minister usurped the drawing up of the district plans.

Originally, Saey proposed to upgrade the smothered parallel channel of decision-making. He thought it should be transformed into a fully-fledged channel that would lead to a geographical pact between the economistic and ecologistic interests involved in the organization of space, comparable with the school pact and the culture pact arrived at through the channel of pacification ${ }^{8}$. Town and country planning is one of the domains of public policy used by defenders of economic development and by the environmental movement to promote their collective interests, and its organization should reflect this 
basic fact (Saey, 1986-87, p. 386; 1990, p. 100-102). Later on, Saey, inspired by the study of decision-making in political Belgium by Dewachter (1992), sided with the idea of grassroots democracy (velddemocratie) (Saey, 1995b, p. 295) ${ }^{9}$. He noticed that spatial planning is also used for the realization of other projects (among them the socialdemocratic and the Flemish projects: Saey, 2001, p. 254). Clearly, the idea of a parallel channel of decision-making as well as the idea of grass roots democracy corresponds to the structure of the societal field of action. Both ideas are examples of an interpenetration of the sphere of popular democratic struggle and the sphere of politics. Both ideas also answer the same purpose of town and country planning, considered as a practical project: the maximal distribution of decision power over the organization of space (Saey, 1986-87, p. 301), the enhancement of the democratic quality of society (Saey, 1995b, p. 293 $)^{10}$. The replacement of aspirations such as sustainable spatial development or a rational and harmonious use of space for the benefit of the economy, the quality of housing and the beauty of the landscape, by the aspiration for democratic control of the organization of space is intended to counter the tendency of the practical project of town and country planning to fail. If function (co-ordination of public policy and private initiatives regarding land use) and task (regulations) are adapted to this purpose, it becomes an antidote against conceptual rigidity and allows goal displacements. One might say that it makes the tendency to fail irrelevant.

\section{The problem of effective governance: the example of collaborative spatial and environmental planning}

\section{Enlarged rationality and consensus-building}

Planning theories set out to improve planning practice (Houthaeve, 1999, p. 133). This can be done in two ways. Most planning theories try to define the features of planning that make it a more effective form of decision-making and policy implementation, and insist that town and country planning should be organized according to this definition. This may easily lead to the application of a formal theory of praxis, as, for example, Albrechts $(1989$, p. 59) found with respect to voluntary planning: «Planning tried, instead of fitting in with reality, to realize itself actively and naively as that reality.» Other theories try to define the limits that social structures and power relations impose on planning, whatever the features may be that would ideally make this style of governance more effective. The theory of Saey (spatial planning is a practical project, in which a social struggle for collective interests is regulated) belongs to the second category. Referring to certain controversies about the new Flemish planning system, he asserts «one continues trying to define the rationality of planning and forgets to ask the question: whatever this rationality may be, does the social order permit this rationality to unfold, and, in the case of a negative answer, what should or could be done?» (Saey, 2001, p. 255).

Saey developed his theory through an analysis of the official documents concerning the setting up and functioning of the then Belgian/Flemish planning system and of the theoretical literature that informed the writings of Flemish planners, who, at first, urged the public authorities to install a planning system and later made proposals to improve the system that was installed. Initially, the planners took an explicitly technocratic stand, based on substantive rationality. They could not understand why many - mainly, but not exclusively, local - authorities were not convinced of the necessity of town and country 
planning. However, the district plans drawn up between 1965 and 1982 can hardly be called technocratic plans. The planners were forced to make heavy concessions to all kinds of private, sectional, and local interests. The then competent Minister did not want to defend plans which would not meet with the approval of the majority of the population (i.e., the elected representatives and traditional interest groups), and established extralegal advisory committees to guarantee this approval. In this manner, civil society already participated in the planning process. It should also be noted that, during the parliamentary discussion of the Town and Country Planning Bill of 1961/62, a number of Members of Parliament objected to the creation of Town and Country Planning Commissions, arguing that these commissions encroached on the constitutional power of elected authorities. Not only did civil society participate in the planning process, but the role of government with respect to the implementation of the plans was also largely limited to the approval or prohibition of private initiatives (by granting or refusing allotment and building licences). Thus, the planning community consisted not only of public authorities and planners, but also of sections of civil society, and the government had only limited steering power. Nevertheless, it would be a great exaggeration to speak of networked governance (as opposed to hierarchical government) or of an enabling state (as opposed to a patronizing state). However, Flemish planners were not satisfied with physical planning and they exerted pressure to apply a new type of planning. After only two decades, the Flemish government commissioned Albrechts and Vermeersch to draw up the Spatial Structure Plan of Flanders, for which the Planning Decree of 1996 would provide the legal framework. In 1999 the Town and Country Planning Act of 1962 was replaced by the Town and Country Planning Decree ${ }^{11}$, which establishes a system of structure planning ${ }^{12}$. Actually, this system is a halfway house between the former physical planning and the theoretical structure planning ${ }^{13}$, which was advocated for the first time on the academic level by Vermeersch back in 1975 and 1977. The further development of the theory on structure planning emphasized, among other things, the increasing socialization of spatial planning, which entailed the necessity of the enlargement of the planning community ${ }^{14}$.

Shortly after the approbation of the Spatial Structure Plan of Flanders, Albrechts explored new paths in spatial planning:

"Thoughts are increasingly going in the direction of interactive decision making on complex problems. This development is often captured by the change from 'government' (the public authorities who impose everything) to 'governance', whereby a more pluralistic form of management is striven for and whereby communication and the creation of a social basis are very important elements. A combination of strategic planning with a more interactive policy, fed by a communicative/collaborative approach, seems to be the direction of the developments in many places ... The unstoppable process of political and governmental modernization, which presents itself internationally, shows a clear shift towards a style of decision-making whereby the stakeholders become increasingly involved in the solution/approach of problems on the basis of a common definition of the situation of departure and the search of a consensus about interests, goals and actions. This results in the participation of more actors, an increasing involvement of the private sector, an increasing self-consciousness of the citizen who rightly wants to have more say in the development of his space of existence» (Albrechts, 2001, p. 68-69).

The consensus in the collaborative approach is said to be of a different nature than, for example, the reconciliation of all opposite interests aimed at in the erstwhile Flemish planning. It is a consensus about discourses, knowledge, systems, and meaning; in short, 
world-views that do not just give different descriptions of reality, but actually constitute different realities. Reality is socially constructed and made up by objects, facts, values, and social relations leading to various perceptions and conceptions of «what is» (Albrechts and Denayer, 2001, p. 372). «Consensus-building has to let unfold human plurality and to respect the different world-views and multiple truths» and the «planner has to be able to act as a mediator between his or her own world-view and all the other world-views concerned as well as between the different world-views planners have to bring in communication with each other». The difficulty is that in order to be able to do that, the planner has to be «an understander and beholder of a meta-language that, following postmodernism, cannot exist» (ibid., p. 373). A way out of this difficulty is not to take identities for granted and «to recognize that people can act together without a strong sense of an 'us' in the traditional sense, such as the family, the neighbourhood, the Gemeinschaft, the party affiliation, the nation and so forth» (ibid., p. 379; italics in the original). In the strategic approach, stakeholders are brought in communication with each other according to the problem that has arisen. Strategic planning in this communicative sense empowers «a 'community', seen as something without boundaries, without knowing beforehand what political forms and goals will be agreed upon» (ibid.; italics in the original).

Communicative/collaborative planning relies on an enlarged form of rationality, communicative rationality. As Braeckman says, since at least the late 18th century modernity has been accompanied by intellectual counter-movements reflecting the negative aspects of modernity. Two examples are Romanticism and postmod-ernism. On every occasion, these movements give a similar definition of the problem, but their answers are extremely diverse. On every occasion, modernity (or the Enlightenment) is accused of untenable reductionism. It narrows down rationality to intellectual, technical, instrumental, and means-end rationality. Usually, a broader type of rationality is then put forward to save what this reductionist conception of rationality denies, oppresses, or excludes (Braeckman, 2002, p. 96-97). Communicative rationality is such a broader type of rationality. It was advanced by Habermas. Habermas recognizes that, in contrast to former societies, modern society is characterized by rationality (giving good reasons). It is increasingly liberated from the pressure of tradition. However, there are two processes of rationalization going on. The first characterizes economy and state, and the second characterizes the life-world (the private world and the public realm). Economy and state rest on means-end action, whereas the life-world has to rely on communicative action and argumentative agreement. Means-end action involves instrumental rationality. The goal is the realization of particularistic ends within the framework of self-preservation. Communicative action involves communicative rationality. The goal is shared understanding, the common definition of reality (Kunneman, 1985).

The question is, how strategic consensus-building and communicative rationality guarantee effectiveness. I will try to answer this question by comparing the work of Healey on spatial and environmental planning of 1997 - as yet the most elaborate version of collaborative planning - with the ideas of Saey explained in the foregoing paragraphs.

\section{The effectiveness of collabora-tive planning}

There is no doubt that collaborative planning aspires to a democratic society: «the field of spatial planning has the potential, because of the complexity of the issues involved and 
the range of potential people with a stake in them, to make a general contribution to the development of pluralist democratic practices for governance in our unequal, culturally diverse and conflict-ridden society» (Healey, 1997, p. 71). Healey mentions three criteria to judge the quality of planning activities. The first one is the degree to which aims are effectively and efficiently achieved, thereby emphasizing that the definition of what are desirable outcomes and how these may be achieved is not as straightforward as instrumentalist rationality ${ }^{15}$ assumes. People change their ways of doing things and seeing things, and undertake their activities within a changing frame of reference. What the outcomes are is difficult to say in advance. The second criterion is the degree to which new links are forged and maintained, appropriate to the particular history and current circumstances in the area. Planning should allow for learning during policy development and implementation processes. The third criterion is the degree to which planning recognizes and reaches out to all those with a stake in the locality. Unless all relevant stakeholders are acknowledged in the process, sustainable practices for managing collective concerns about spatial change are out of reach. All three criteria are important, «[b]ut the overarching perspective is that without the third, spatial planning efforts will make little contribution to addressing local environmental conflicts in sustainable ways» (ibid., p. 68-71). Healey's approach «offers a way forward in the design of governance processes for a shared-power world, and takes as a normative position an ethical commitment to enabling all stakeholders to have a voice» (ibid., p. 5; italics in the original omitted). All this bears a strong resemblance to Saey's proposition to replace the criterion of the best possible decision by the criterion of the best possible way to make a decision. As many people as possible should be allowed to participate in decision-making, i.e., the set of people who are able to contribute to the understanding of the object of decision-making and/or to which the decision-making applies (Saey, 1995a, p. 162). This participation is required for two reasons: to deal appropriately with unintentional undesired effects, and to realize democracy because it is a value in itself (ibid.; Saey, 1995b, p. 293). Healey discusses in detail how a stakeholders' community can be created and how it can be put to work. She seems to fill out Saey's proposition, which was framed in general terms only. However, whether this is indeed the case depends on the theory of praxis and the structure of the social field of action that Healey has in mind.

Healey develops an institutionalist approach to understanding urban and regional change. She focuses on those social relations through which daily life and business organization are conducted, as well as on the way social and biosphere relations interweave, and acknowledges that the structures of economic relations and state organization shape the opportunities and values of individuals (Healey, 1997, p. 5, 56). Clearly, the work of Healey is immune to the criticism Saey made about much planning research. Usually, the formulation of ends regarding the organization of space is preceded by an elaborated study of the existing organization. A comparable analysis of the existing decision-making processes is seldom made. One immediately proceeds to the formulation of how the decision-making process is to be organized (Saey, 1986-87, pp. $265-266 ; 1990$, p. 98,107$)$. That is precisely why many planning theorists forget to ask the question about whether social structures and power relationships will permit the unfolding of the rationality of planning. Healey does not forget this question. She examines which forms of governance might favour the evolution of a democratic, policydriven planning culture, and which forms might inhibit it. By forms of governance, she means existing western governance systems: representative democracy, pluralist 
democracy, corporatism, and clientelism (Healey, 1997, p. 219-230). So this criticism does not apply to her. The convergence of Healey's institutionalist approach and Saey's Marxist approach breaks down at another point, viz., the influence of the theory of communicative action of Habermas and of the structuration theory of Giddens on Healey's thought.

Communicative action in the sense of Habermas appears to imply a search for a metalanguage. Only those intuitions deserve the qualification «ethical» which are the object of a rational consensus within a communicative community. Ethical orientations that are not rationally justified are gratuitous, subjective, non-committal, and necessarily out of control. A normative position is only rational when it can be universalized. Therefore, criteria ought to be established which decide on the possibility of the universalization of a certain norm in order to conclude that the norm is rational and legitimate. Lyotard argued against this reasoning that ethical orientations toward equality and emancipation change into a totalitarian normative code from the moment a legitimizing narrative tries to give them a rational foundation. Ethical orientations should be protected against all types of logic of legitimization. Each discourse homogenizes. It wants to impose and maintain its own specific logic. As a consequence, it provokes insoluble conflicts between incommensurable types of logic. Instead of trying to achieve a rational consensus within a situation of communication between equals, one ought to give voice to the radical Other, to the always endangered and necessarily excluded alterity (Braeckman, 2002, pp. 100-104). The argumentation of Lyotard is self-destructive. The alterity is unknowable by definition. Consequently, somebody within a certain order cannot see what is excluded by that order, and somebody outside the order cannot appreciate the possibility of a conflict between what is included in the order and what is excluded by the order (ibid., p. 107). Nevertheless, there remains a problem with respect to collaborative planning that is obviously related to the criticism of Lyotard on Habermas, even when we take into account that collaborative planning has gone beyond Habermas by defining a stakeholder community without boundaries. It might well be that strategic consensus-building can only be realized on condition that the elaboration of certain ideas is prematurely halted (Saey, 2001, p. 253, referring to Albrechts et al., 1999), in other words that certain worldviews do not have the voice they deserve.

However, the decisive point of divergence between the approaches of Healey and Saey is, not unexpectedly of course, the field of action implied in the theory of structuration. In this field of action, the class relations (the relations of production) are merely one of many societal relations of equal importance. The sphere of popular-democratic struggle has absorbed the sphere of reproduction and penetrates to a much higher degree (than in the field of action envisaged by Cooke and Saey) into the spheres of production and of politics. Moreover, these spheres are no longer loci of social struggle, but loci of struggle and strategic consensus-building. This reshuffling of the field of action undeniably reflects the restructuring of the mode of production since the seventies/eighties (the shift from the Keynesian welfare state to the Schumpeterian workfare state), and the accompanying declining power of traditional interest groups (corporatist and pillar organizations $)^{16}$, but these developments allow of two interpretations. These are, that either the structuring of the space of action into a field of social struggle between bearers of collective interests is obsolete and is correctly replaced by the structuring into a field of action of stakeholders or stakeholder communities without boundaries; or that the said developments are a result of the changing importance of the different spheres, without 
affecting their existence, and the structuring of the space of action into a field of action of stakeholders is based on an incorrect transformation of epiphenomena into basic ontological features. If the latter interpretation is true, collaborative planning employs a formal theory of practice. It formulates a theory of decision-making and policy implementation (strategic consensus-building between stakeholders), that functions within a broader field of social struggle for collective interests, but it nevertheless takes for granted that society will yield (maybe after quite a lot of opposition and resistance) to the kind of governance that the theory requires, because it imagines a society that in its entirety functions on the basis of consensus-building between stakeholders. In this case, it is to be expected that collaborative planning will strengthen, or at least leave unaffected, the social structures and power relations that generated the very problems that this type of networked governance is intended to solve. In a comparison between the structuration theory of Giddens with, among other things, the thesis of Saey on the manner in which it can be said that society is (un)makable, Meert has arrived at the same conclusion. The theory of structuration, he says, neglects the societal relations that profoundly influence the social production of space. It neglects the degrees of freedom that the actors have at their disposal to make society by means of spatial interventions. According to Meert, Giddens accepts the process of structuration as an isolated phenomenon without paying attention to the underlying processes that produce rules and resources. He merely observes that structures function as rules and resources and that they can be changed, but he does not ask why these rules and resources exist and why they are changed in a particular way (Meert, 2000, p. 289).

\section{Conclusion}

One way to define the problem of effectiveness of spatial planning is to consider spatial planning as a large-scale practical project and to analyse it by means of the categories that explain why this type of project has the tendency to fail and how this tendency can be countered. The theory of Saey (spatial planning is a field in which a social struggle for collective interests is regulated) and the theory of Healey on collaborative spatial and environmental planning, when analysed in terms of these categories, indicate the same way to counter the tendency to fail. The purpose or aspiration of the practical project of spatial planning should be enhancing the democratic quality of society. Healey firms up how this could be realized by strategic consensus-building within stakeholder communities without boundaries. However, the effectiveness of this method depends on the social field of action that Healey's institutionalist approach implies. Insofar as this approach structures the space of action as a field of stakeholders, collaborative planning employs a formal theory of praxis. A theory of governance is then substituted for a theory of society. As a consequence, it is to be expected that collaborative planning will strengthen, or at least leave unaffected, the social structures and power relations that generated the very problems that it is intended to solve. Insofar as this approach structures the space of action as a complex of more or less interpenetrating spheres that are loci of social struggle for collective interests, collaborative planning could correspond to the theory of Saey who employs a structural theory of praxis. However, this conclusion itself depends on the tenability of the view of the social field of action as a field of struggle, in spite of the recent restructuring of the mode of production and the associated decline of the power of traditional interest groups, which at first sight seem to 
necessitate a fundamental reshuffling of the field of action. As collaborative spatial and environmental planning is a textbook example of networked governance, the result of this reflection on the problem of effectiveness can probably be generalized over other fields of governance than the organization of space.

\section{BIBLIOGRAPHY}

ALBRECHTS L. (1989), «Enkele reacties op de beslissingsgerichte benadering», Planologisch Nieuws, 9, pp. 58-61.

ALBRECHTS L. (2001), «Het spanningsveld 'ruimte en economie' als vertrekpunt voor het verkennen van nieuwe wegen voor de ruimtelijke planning», Ruimte \& Planning, 21, pp. 65-70.

ALBRECHTS L., DENAYER W. (2001), «Communicative planning, emancipatory politics and postmodernism», in PADDISON R. (ed.), Handbook of Urban Studies, London, Sage, pp. 369-384.

ALBRECHTS L., VAN DEN BROECK J., VERACHTERT K., LEROY P., VAN TATENHOVE J. (1999), Geïntegreerd gebiedsgericht beleid, een methodiek, K.U.Leuven, K.U.Nijmegen, AMINAL.

BRAECKMAN A. (2002), «Lyotard en Habermas. Twee visies op uitsluiting en hoe eraan te verhelpen», in SAEY P., MESTRUM F., TINNEVELT R., BRAECKMAN A., Ruimte voor het verhaal van de andere. Over het in- en uitsluitend vermogen van het denken en het discours, Mechelen, Berchem, CIMIC, EPO, pp. 95-108.

COOKE PH. (1983), Theories of planning and spatial development, London, Hutchinson.

DEWACHTER W. (1992), Besluitvorming in politiek België, Leuven, Acco.

DEWACHTER W. (2001), De mythe van de parlementaire democratie, een Belgische analyse, Leuven, Acco.

ENGELS F. (1971), De ontwikkeling van het socialisme van utopie tot wetenschap, Sunschrift 39, Nijmegen, SUN.

HEALEY P. (1997), Collaborative planning. Shaping places in fragmented societies, Basingstoke, Macmillan.

HOUTHAEVE R. (1999), Ruimtelijke planvorming in actie: conceptie en toepassing van een 'collaboratieve planningspraktijk' in Vlaanderen. Met illustratief cases-onderzoek, Ongepubliceerd proefschrift, Universiteit Gent, Faculteit Wetenschappen.

HUYSE L. (1981), «De Belgische ziekte», De Nieuwe Maand, 24, pp. 322-331.

HUYSE L. (1983), «Breuklijnen in de Belgische samenleving», Tijdschrift voor Sociologie, 4, pp. 9-25.

KREUKELS A. (1980), Planning en planningproces. Een verkenning van sociaal-wetenschappelijke theorievorming op basis van ruimtelijke planning, Den Haag, VUGA Boekerij.

KUNNEMAN H. (1985), Habermas' theorie van het communicatieve handelen, een samenvatting, Meppel, Boom.

MEERT H. (2000), «Giddens' structuratie-theorie en de maakbaarheid van de samenleving door ruimtelijke planning», Ruimte \& Planning, 20, pp. 277-294. 
RAVETZ J.R. (1973), Scientific knowledge and its social problems, Harmondsworth, Penguin Books.

SAEY P. (1986-87), Sociale geografie en de ordening van de ruimte in Vlaanderen op macro-niveau: de theoretische grondslagen van een praktisch probleem, Ongepubliceerd proefschrift, Universiteit Gent.

SAEY P. (1988a), De eerste generatie projecten van ruimtelijke ordening op macro-niveau in Vlaanderen, Publikaties van het Seminarie voor Menselijke en Ekonomische Geografie der Rijksuniversi-teit Gent, nr. 17.

SAEY P. (1988b), «De zelfperceptie voorbij: ruimtelijke ordening als praktisch project. 1. Analyse van een mislukking», Planologisch Nieuws, 8, pp. 54-66.

SAEY P. (1988c), «De zelfperceptie voorbij: ruimtelijke ordening als praktisch project. 2. Ruimtelijke organisatie en maatschappelijk actieveld», Planologisch Nieuws, 8, pp. 180-193.

SAEY P. (1989), «De zelfperceptie voorbij: ruimtelijke ordening als praktisch project. 2b. De maatschappelijke betekenis van de ruimtelijke ordening», Planologisch Nieuws, 9, pp. 18-30.

SAEY P. (1990), «De zelfperceptie voorbij: ruimtelijke ordening als praktisch project. 3. Contouren en relevantie van een maatschappelijke theorie voor de planmatige organisatie van de ruimte», Planologisch Nieuws, 10, pp. 97-109.

SAEY P. (1995a), «Omtrent de maakbaar-heid van de samenleving door ruimtelijke planning, deel 1: er is maakbaarheid en er is maakbaarheid», Planologisch Nieuws, 15, pp. 159-167.

SAEY P. (1995b), «Omtrent de maakbaar-heid van de samenleving door ruimtelijke planning, deel 2: ruimtelijke ordening als maatschappelijk gebeuren», Planologisch Nieuws, 15, pp. 279-299.

SAEY P. (1995c), «Marxisme, elementen voor een herijking», Vlaams Marxistisch Tijdschrift, 29, pp. 177-188.

SAEY P. (2001), «Listen very carefully, I’ll say it once again», Ruimte \& Planning, 21, pp. 253-257.

VAN DER VALK A. (1989), Amsterdam in aanleg; planvorming en dagelijks handelen 1850-1900, Planologische Studies, nr. 8, Planologisch en Demografisch Instituut, Universiteit van Amsterdam. VERMEERSCH CH. (1975), «De structuurplanning, een geldig alternatief?», Stero, nr. 10, pp. 24-34.

VERMEERSCH CH. (1977), De structuur-planning als type ruimtelijke planning: een geldig alternatief, Brussel, CIAUD/ICASD.

VERMEERSCH CH., m.m.v. HOUTHAEVE, R. (1994), Structuurplanning. Instrument voor het denken over en de vormgeving aan de ruimtelijke structuur, Brugge, Die Keure.

WALLAGH G. (1990), Kader voor beslissingsgericht onderzoek. Theoretisch kader voor het onderzoek 'strategisch ruimtelijke planning in Amsterdam en omgeving, vanaf 1955'. Werkstukken, nr. 117, Planologisch en Demografisch Instituut, Universiteit van Amsterdam.

ZONNEVELD W. (1991), Conceptvorming in de ruimtelijke planning, Planologische Studies, nr. 9A en 9B, Planologisch en Demografisch Instituut, Universiteit van Amsterdam.

ZONNEVELD W. (1998), «De noodzakelijke heroriëntatie van de Nederlandse ruimtelijke ordening», Planologisch Nieuws, 18, pp. 151-168.

\section{NOTES}

1. Town and Country Planning Decree of 18 May 1999, art. 4: «Town and country planning is directed to sustainable spatial development ...». 
2. In Ravetz, the goal of the task, purpose, and function are Aristotelian final causes.

3. 'View' and 'design' replace the original terms, objectives (doelstellingen) and strategy.

4. I take these terms from Zonneveld (1998), who uses them to refer to the key tasks or basic principles of Dutch town and country planning.

5. A pillar is a system of organizations (networks of schools, trade unions, health services, cultural funds, women's federations, youth associations, sports federations, etc.) avowing an ideological conviction, whereby the function of umbrella organization is performed by a political party of the same ideological conviction.

6. Saey does not make the analytical difference between, on the one hand, space of action, and, on the other hand, field of action (the space of action structured by ideology and ensuing action), but merges the two in one single concept.

7. Saey's version of historical materialism is freed from metaphysics (history has an immanent purpose) and a number of outmoded theories such as the labour theory of value (Saey, 1995c).

8. The school pact is an agreement between Catholics, who defended the Catholic network of schools, and socialists and liberals, who defended the state network of schools, to end the school war which broke out as a result of the alleged discrimination of the Catholic network by the government of liberals and socialists (after the alleged preferential treatment of that network by the former government of Christian Democrats). The pact, concluded in 1958, was given legal force by the Act of 1959. The culture pact, concluded and given legal force in 1972, is an agreement between Catholics, liberals and socialists to prevent discrimination of minorities.

9. Interest groups, activists, organizations, and movements of civil society are entitled to place their issues on the political agenda and to enforce an appropriate treatment of their solutions by the elected authorities in all stages of the process of decision-making.

10. The second phrasing takes into account that «[p]ower is not a possession that can be abstracted from its owners and distributed democratically into society» (Albrechts and Denayer, 1977, p. 380).

11. Town and country planning has become an exclusive power of the regions (Flanders, Wallonia, and Brussels-Capital), which make decrees (in the case of Brussels' ordinances) instead of laws or acts. The decrees and ordinances have the same legal force as the laws of the federal government. However, the ordinances of the Brussels-Capital Region on town and country planning are subject to the control of the federal state, whereas the decrees of the Flemish Region and the Walloon Region are not.

12. The Decree defines three levels of spatial planning, the regional (in the sense of federated entity), the provincial, and the municipal. The region and each of the provinces and municipalities draw up a spatial structure plan and spatial execution plans. Spatial execution plans conform to a spatial structure plan, whereas the plans of a lower authority conform to the plans of a higher authority. Spatial execution plans are binding and will replace the district and municipal plans based on the Town and Country Planning Act of 1962, and spatial structure plans are binding upon the public authorities. The levels of spatial planning thus coincide with the administrative levels in contrast to the levels of spatial planning defined by the Town and Country Planning Act of 1962. The drawing up of regional and district plans was the task of the central state. The districts were subdivisions of provinces and were composed of municipalities, but they did not coincide with an area of an administrative entity. All plans were binding.

13. It is symptomatic that Dewachter (2001) discusses the Spatial Structure Plan of Flanders in the chapter on technocratic decision-making.

14. However, in an updating of the theory in 1994, Vermeersch and Houthaeve, referring to the public private partnership in which property developers often dominated, had to regret the elitist character of the enlargement of the planning community.

15. Actually, Healey refers to rationalist policy analysis. 
16. Declining power also in the sense that they lose their hold on individuals (who, e.g., join associations of different pillars or ideological inclinations).

\section{ABSTRACTS}

This article discusses the problem of the effectiveness of spatial planning by means of a comparison between the theory of Saey (spatial planning regulates a social struggle for collective interests) and collaborative planning as elaborated by Healey, starting from the viewpoint that spatial planning is a large-scale practical project. This type of project has a built-in tendency to fail. Saey and Healey present a similar way out, considering that the purpose of spatial planning should be the attainment of democratic quality in society. However, they diverge with respect to the societal field of action that they envisage. The societal field of action in Healey's approach seems to imply a formal theory of praxis. A theory on governance threatens to replace a theory of society. This raises doubts about the effectiveness of collaborative planning. As (spatial) planning is a style of governance in the general sense (management of collective affairs), and collaborative planning is a textbook example of networked governance (as opposed to hierarchical government), this conclusion may be generalized to other forms of governance.

Dit artikel bespreekt het probleem van de effectiviteit van ruimtelijke planning aan de hand van een vergelijking tussen de theorie van Saey (ruimtelijke planning reguleert een sociale strijd voor collectieve belangen) en de collaboratieve planning, zoals Healey deze heeft uitgewerkt. Het vertrekpunt daarbij is de opvatting van ruimtelijke planning als grootschalig praktisch project. Een dergelijk project heeft een ingebouwde tendens tot mislukken. Saey en Healey presenteren een gelijkaardige uitweg, namelijk dat ruimtelijke planning moet bijdragen aan het democratisch gehalte van de samenleving. Zij hebben echter een verschillende opvatting over het maatschappelijk actieveld. Healeys opvatting van het maatschappelijk actieveld blijkt een formele theorie van de praxis te impliceren. Beleidstheorie dreigt in de plaats te treden van maatschappijtheorie. Dit doet twijfels rijzen aangaande de effectiviteit van collaboratieve planning. Aangezien (ruimtelijke) planning een stijl van governance is (management van collectieve zaken) en collaboratieve planning een schoolvoorbeeld van genetwerkte governance (in tegenstelling tot hierarchisch bestuur) kan deze conclusie veralgemeend worden tot andere vormen van governance.

\section{INDEX}

Trefwoorden collaboratieve planning, Vlaanderen, governance, praktisch project, ruimtelijke planning, theorie van de praxis

Keywords: collaborative planning, Flanders, governance, practical project, spatial planning, theory of praxis 
AUTHOR

PIETER SAEY

Department of Geography, Faculty of Sciences, Ghent University, Belgium, piet.saey@rug.ac.be 